\title{
Analysis of Characteristics of and Use Value of Mangrove Ecosystem (Case Study in Samataring and Tongketongke Sub-Districts, Sinjai Regency)
}

\author{
Abdul Haris Sambu \\ Faculty of Agriculture, Department of Aquaculture Muhammadiyah University of \\ Makassar, Indonesia \\ E-mail: abdulharis_spi@gmail.com
}

Rahmi

Faculty of Agriculture, Department of Aquaculture Muhammadiyah University of Makassar, Indonesia

A. Khaeriyah

Faculty of Agriculture, Department of Aquaculture Muhammadiyah University of Makassar, Indonesia

Received: October 7, 2014 Accepted: December 2, 2014 Published: December 25, 2014

doi:10.5296/jee.v5i2.6826 URL: http://dx.doi.org/10.5296/jee.v5i2.6826

\begin{abstract}
The study is performed in Samataring and Tongketongke sub-districts, East Sinjai District, Sinjai Regency, South Sulawesi, Indonesia. It aims at identifying species composition of mangrove vegetation, analyzing characteristics of mangrove ecosystem, and studying economic valuation of mangrove ecosystem. Identification on the three research sites found four types of mangrove vegetation by $86.53 \%$ Rhizophora, $7 \%$ Bruguira, $4.15 \%$ Avicennia, and $2.34 \%$ Senneratia; characteristics of mangrove ecosystem are absolute density by 1.01 $\mathrm{m}^{-2}$ or 10.010 plant $\mathrm{m}^{-1}$, relative density covers: Rhizophora $87.76 \%$, Bruguira $6.70 \%$, Avicennia 3.90\%, and Senneratia 2.13\%. Relative density covers Rhizophora, Bruguira, Avicennia, and Senneratia. Average relative frequency is $22.23 \%$, relative closure covers: Rhizophora 28.84\%, Bruguira 29.08\%, Avicennia 28.10\%, while importance value index
\end{abstract}




\section{Macrothink}

covers: Rhizophora 138.36\%, Bruguira 57. 99\%, Avecennia 54.21\%, and Senneratia 48.90\%. Economic valuation of mangrove ecosystem covers direct use value of Rp48,303,875 $\mathrm{ha}^{-1}$ year ${ }^{-1}$, indirect use value of Rp3,338,650 $\mathrm{ha}^{-1}$ year $^{-1}$, alternative use value of Rp142,500 ha ${ }^{-1}$ year $^{-1}$, and existence use value of Rp3,917,722 ha $^{-1}$ year $^{-1}$.

Keywords: species composition, characteristics, valuation of mangrove 


\section{Introduction}

Mangrove ecosystem is one of coastal ecosystem. In the end of the 21 st century, this area keeps decreasing as the consequence of various appropriation. Based on the data in 1982, area of mangrove is 5,209,543 ha and in the end of 1999, the remaining area is just 2,346,414 ha. It means that, for 17 years, mangrove ecosystem in Indonesia keep decreasing around $54 \%$ or $3.2 \%$ per year (Sofyan, 2001). One of causal factors of this phenomenon is appropriation for brackish-water pond, where one of the triggers is Presidential Decree No. 39 of 1980 on trawl operations in Indonesian waters in purpose to protect waters biodiversity, especially tiger prawn.

The impact of the Presidential Decree are declining of tiger prawn production which has been caught from the sea, at the same time import demand keep raising that one of the effort to meet the demand is brackishwater culture by converting mangrove forest into brackishwater pond on a large scale. Unfortunately, without their being aware of it, mangrove forest conversion decreases coastal resource and affects other coastal ecosystem like seaweed bed and coral reef that it decreases biodiversity in coastal waters (Beukeboom, et al., 1992)

To conserve condition of mangrove ecosystem in Indonesia, Act No 5 of 1990 concerning conservation of living resources and their ecosystem is applied. However, government efforts to conserve mangrove ecosystem in Indonesia by planting mangrove in various regions in Indonesia, including Sinjai Regency, works well in quantity, but it is not in the matter of quality. Diversity conservation of mangrove ecosystem tends to be homogeneous and it is dominated by certain species that use value of mangrove ecosystem is unmatched with natural growth of mangrove ecosystem as it has high heterogeneity (Supriharyono, 2005).

The study aims at (1) identifying species composition of mangrove vegetation, (2) analyzing characteristics of mangrove ecosystem, involving absolute density, relative density, relative frequency, relative closure, and importance value index, (3) studying economic valuation of mangrove ecosystem, covering direct use value, indirect use value, alternative use value and existence use value.

\section{Research Method}

\subsection{Research Time and Research Site}

The study is performed for six months form January to June, 2014. Research site is located in Samataring village and Tongketongke village, East Sinjai District, Sinjai Regency, South Sulawesi Province, Indonesia.

\subsection{Scope of Research}

Scope of research is in coastal area of Sinjai Regency by choosing two coastal villages, i.e. Samataring village and Tongketongke village. These two villages are picked based on consideration that the location may represent characteristics of mangrove ecosystem in Sinjai Regency. 


\subsection{Data Source}

Data sources used in the study are primary data and secondary data. Used primary data to identify types of mangrove vegetation and characteristics of mangrove ecosystem is obtained by direct observation and survey in the field, while primary data on condition of mangrove ecosystem and direct use value of brackishwater and mangrove ecosystem is obtained by direct interview with aquaculturist and fisherman. Secondary data in form of general overview of coastal area in Sinjai Regency is obtained by test book consisting of previous research findings and book of Central Statistics Body of Sinjai Regency.

\subsection{Data Collection Technique}

Setting up research site is divided into three ecosystem, consisting of (1) mangrove ecosystem in Samataring village, (2) mangrove ecosystem, and (3) mangrove ecosystem of silvofishery. Every observed ecosystem is divided into three observation transect. Afterwards, observation of mangrove vegetation is performed by the following steps: (1) making of transect at size of $10 \times 10$ meter, (2) calculating amount of vegetation within transect, (3) identifying type of mangrove vegetation, and (5) studying and analyzing economic valuation of mangrove ecosystem.

\subsection{Observed Variables}

Variables observed, calculated, and analyzed in the study are: (1) species and composition of vegetation, (2) characteristics of mangrove ecosystem, consisting of absolute density, relative density, relative frequency and importance value index, (3) economic valuation of mangrove ecosystem, such as direct use value, indirect use value, alternative use value and existence use value.

\subsection{Data Analysis}

Data analysis applied in the study consists of absolute density, species density, relative density, relative frequency, relative closure, importance value index, and use value of mangrove ecosystem. To analyze characteristics and use value of mangrove ecosystem, equation introduced by Bengen (2002) is applied as presented one by one below.

\subsubsection{Relative Density}

Relative density of mangrove vegetation is the ratio between amount of the $i$ th tree stand species and total of all tree stand species. To analyze relative density of mangrove vegetation, it applies the following equation 1 .

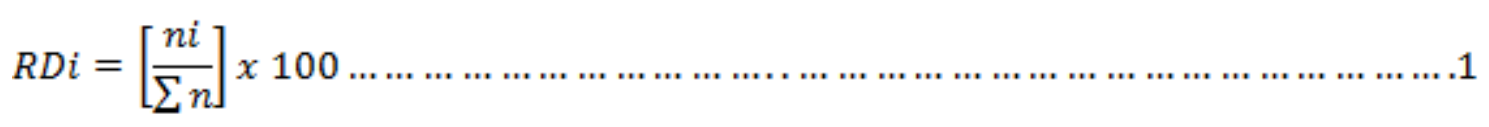

Information:

Rdi: Relative Density

ni: Total Amount 
$\sum \mathrm{n}$ : Total stand of all species.

\subsubsection{Relative Frequency}

Relative frequency is ratio between frequency of the $i$ th species and total frequency of all species in mangrove vegetation. To analyze relative frequency of mangrove vegetation, it applies equation 2 .

$$
R F i=\left[\frac{F i}{\sum F}\right] \times 100
$$

Information:

Rfi : Relative frequency of the ith species

Fi : Frequency of the $i$ th species

$\sum \mathrm{F}$ : Total amount of made sample plot (3 Plots)

\subsubsection{Relative Closure}

Relative closure of mangrove vegetation is ratio between closure of the $i$ th species and area of total closure of all species. To analyze relative closure of mangrove vegetation, it applies the following equation 3 .

$$
R C i=\left[\frac{C i}{\sum C}\right] \times 100
$$

Information:

RCi : Relative Closure

$\mathrm{Ci}:$ Closure of the $i$ th species

C : Total closure of all species

3.6.4 Importance Value Index

Importance Value Index (IVI) is sum of relative density (RDi), relative frequency (RFi) and relative closure $(\mathrm{RCi})$. To analyze importance value index of mangrove vegetation, it applies the following equation 4 .

$$
\mathrm{IVI}=\mathrm{RDi}+\mathrm{RFi}+\mathrm{RCi}
$$

Information:

IVI: Importance Value Index

RDi : Relative Density

RFi: Relative Frequency

RCi: Relative Closure 


\subsubsection{The Use of Mangrove Ecosystem}

Total economic value of mangrove ecosystem is sum of direct use value, indirect use value, alternative use value, and existence use value of mangrove ecosytem by applying various economic valuation method such as EOP (Effect on Productivity) and TCM (Travel Cost Method) and CVM (Contingent Valuation Method). For example, total economic value (TEV) of mangrove ecosystem which is sum of all use values has been identified by applying the following equation 5, as proposed by Yulianda, et al. (2010)

$$
\mathrm{TUV}=\mathrm{DUV}+\mathrm{IUV}+\mathrm{XV}
$$

Information:

TEV : Total Economic Value

DUV : Direct Use Value

IUV : Indirect Use Value

$\mathrm{XV}$ : Existence Use Value (XV)

Direct use value is shown by coastal fisheries product from mangrove ecosystem. Indirect use value of mangrove ecosystem is shown by the function of being seawall to resist abrasion, in addition to the function of preventing salt water intrusions into the ground, protecting the residential area from whirlwind and provider of various nutritive substances for marine biota. Alternative use value is shown by environmental services as a place of ecosystem, and existence use value is indicated by the function when mangrove ecosystem is able to protect the ground from natural disasters such as tsunami and swell.

\section{Findings and Discussion}

\subsection{General Overview}

Samataring village and Tongketongke village, East Sinjai District, Sinjai Regency are at southern latitude of $5^{0} 19^{\prime} 30^{\prime \prime \prime \prime}$ to $5^{0} 36^{\prime} 47^{\prime \prime}$ and at longitude east of $119^{\circ} \quad 48^{\prime} \quad 30^{\prime \prime}$ to $120^{\circ}$ 20 '00". Sinjai Regency has potential capability to develop fisheries product either cultivated or caught fisheries, and it has shoreline of $31 \mathrm{~km}$ consisting of $17 \mathrm{~km}$ length in the land and $14 \mathrm{~km}$ length in Nine Islands. For the shoreline length of Sinjai Regency, mangrove ecosystem is spread by $1,351.50$ ha and it has potential brackishwater in an area of 1,033.50 ha, but it has only 716.50 ha or $69.33 \%$ of the potential area which has been managed well (Fisheries and Marine Services, 2012).

Samataring village and Tongketongke village are the two villages of nine coastal villages in Sinjai Regency. People of Samataring village has planted mangrove in an area of 280.50 ha which is spread throughout the shoreline of $2.5 \mathrm{~km}$ length, while people of Tongketongke has planted mangrove in an area of 350.00 throughout the shoreline of $2.5 \mathrm{~km}$ length. Besides, these two villages has potential brackishwater pond, i.e. Samataring village has 101.50 ha or $14.16 \%$ area of brackishwater pond in Sinjai Regency, and Tongketongke village has 56.68 or 7.91\% area of brackishwater pond in Sinjai Regency (Fisheries and Marine Services, 2012).

The following is average production of brackishwater pond in Sinjai Regency: (1) tiger prawn reaches $168.6 \mathrm{~kg} \mathrm{ha}^{-1}$ year $^{-1}$, (2) milkfish reaches $513 \mathrm{~kg} \mathrm{ha}^{-1}$ year ${ }^{-1}$, (3) uncultivated shrimp reaches $40.9 \mathrm{~kg} \mathrm{ha}^{-1}$ year $^{-1}$, and (4) uncultivated fish reaches $86.5 \mathrm{~kg} \mathrm{ha}^{-1}$ year $^{-1}$. Whereas, the following is product of capture fisheries in 2011: (1) 25,806.00 ton (2) 
1,914,500 fry, and (3) 487,000 fishes. Statistically, cultivated fisheries and coastal capture fisheries product in Sinjai Regency is increasing significantly from year to year. This production can not separate from the existence of mangrove ecosystem spread in nine coastal villages in Sinjai Regency, i.e. 1,351.50 ha (2007).

\subsection{Composition of Mangrove Vegetation}

Observation about composition of mangrove vegetation is given to three observation locations, (1) mangrove ecosystem in Samataring village, (2) mangrove ecosystem in Tongketongke village, and (3) silvofishery mangrove. Based on the identification and analysis, mangrove ecosystem in Sinjai Regency has four species where percentage of each species is given below: (1) Rhizophora 86.53\%, (2) Bruguira 7\%, (3) Avicennia 4.15\%, and (4) Senneratia $2.34 \%$. The analysis depicts that mangrove ecosystem in Sinjai Regency after rehabilitation is highly dominated by Rhizopora vegetation almost $90 \%$.

Species composition of mangrove vegetation in the three observed locations shows that heterogeneity or biodiversity is very low. It proves that rehabilitation given to an ecosystem, in quantity, has worked well either in the aspect of area or density. However, it has not achieved good quality since it has not restored or recovered biodiversity as good as previous condition. The findings also depict that adaptability of mangrove vegetation is different either in adaptability to zonation or resilience level. Species Rhizopora is more adaptive to zonation and it can be restored fast compared to other vegetation. Anywhere rehabilitation is given, mangrove ecosystem is mainly dominated by species Rhizopora.

\subsection{Characteristics of Mangrove Ecosystem}

Characteristics of mangrove vegetation as the focus of this study concerns on: (1) absolute density, (2) relative density, (3) relative frequency, (4) relative closure, (5) importance value index, and (6) economic valuation.

\subsubsection{Absolute Density}

Based on the observation and analysis of mangrove ecosystem in the three observed locations, here is average absolute density in every village: (1) Samataring village: 1.03 stands $\mathrm{m}^{-1}$, or

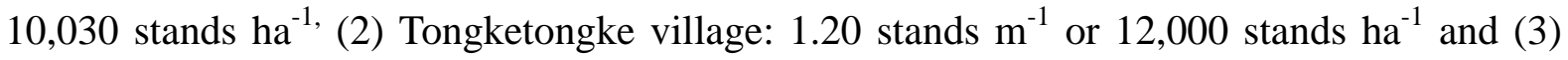
silvofishery brackishwater pond: 0.81 stands $\mathrm{m}^{-1}$ or 81,000 stands ha ${ }^{-1}$. Based on the analysis of absolute density of mangrove vegetation in the three observed locations, average absolute density is 1.01 stands $\mathrm{m}^{-1}$ or 10,010 stands $\mathrm{ha}^{-1}$. Density level of mangrove ecosystem in the three observed locations in Sinjai Regency, if it is referred to the decree of Ministry of Environment of the Republic of Indonesia No 201 of 2004, is very dense as the density is higher than 1,500 stands ha ${ }^{-1}$.

Observation result for mangrove ecosystem shows that density level of this ecosystem is categorized as very dense that it may cause death of trees naturally. Presumably, it is caused by: (1) the trees do not get enough sunlight, (2) the trees do not get maximal nutritive substance, and (3) there is no connected wallow. If the latter causal factor exists, when low tide occurs, vegetation will be dry for one tidal period. Based on the observation and analysis, fatality rate of mangrove tree in the three locations, especially mangrove ecosystem in Samataring village and Tongketongke village, is high from $1 \%$ to $5 \%$ year $^{-1}$. 


\subsubsection{Relative Density}

Based on the performed observation and analysis of mangrove ecosystem in the three observed locations, relative density is calculated by average percentage found in every observed mangrove vegetation: (1) Rhizophora 87.76\%, (2) Bruguira 6.70\% (3) Avicennia $3.90 \%$, and (4) Senneratia $2.13 \%$. Relative density analysis shows that Rhizopora is the most dominant species. Presumably, Rhizopora has not only vast zonation, but also fast growth rate compared to other vegetation types.

Species Rhizopora does not only have vast adaptability in all zones and fast growth rate, but this species also has high recovery rate or resilience level. This becomes causal factor on why in every mangrove ecosystem rehabilitation program is, commonly, dominated by species Rhizophora. Species Rhizophora also has high adaptation to salinity. Based on the findings, this species can be found from zone close by sea water at high salinity to surrounding area of estuary; even, it can also be found in watershed where the salinity is almost fresh.

\subsubsection{Relative Frequency}

Relative frequency analysis is given to three observed locations as follows: (1) Samataring village, (2) Tongketongke village, and (3) silvofishery brackishwater pond. There are four identified species; they are Rhizopora, Bruiguira, Avicennia and Senneratia. Average value of these four species is $22.23 \%$. It means that these four observed mangrove vegetation types have same opportunity to be found in the three observed locations.

\subsubsection{Relative Closure}

Analysis of relative closure of mangrove vegetation in the observed locations found that: (1) Samataring village has average value of 24.99 , (2) Tongketongke village has average value of 32.99 , and (3) silvofishery brackishwater pond has average value of 24.24. This relative density analysis of mangrove vegetation in the three observed locations shows that Samataring village has the highest relative density value compared to the other two locations. Presumably, it is caused by ecological condition in Samataring village which is better and far from residential area that mangrove ecosystem lives far from human activity.

\subsubsection{Importance Value Index}

Importance value index of mangrove vegetation ranges from 0 to 300 . This importance value index will become an overview about influence or role of a plant in community within vegetation ecosystem. Analysis of importance index value of mangrove vegetation in the three observed locations found: (1) Rhizophora reaches 238.36, (2) Bruguira reaches 57.99, (3) Avicennia reaches 54. 21, and (4) Senneratia has 48.90. The findings show that species Rhizopora has the most dominant influence in the three observed mangrove ecosystem.

Based on the analysis of importance value index of mangrove vegetation, composition of vegetation in the three observed locations has high homogeneity, but it has low level heterogeneity. In fact, one of indicators that mangrove ecosystem is healthy is when it has high heterogeneity or when the ecosystem has high biodiversity. It complies with fundamental goals of Act of the Republic of Indonesia No 5 of 1990 regarding conservation of living resources and their ecosystem. Accordingly, if this Act is applied, it will not only conserve flora and fauna, but it will also keep habitat away from irresponsible utilization or hostile-environment utilization. 


\subsection{Use Value of Mangrove Ecosystem}

Mangrove ecosystem has ecological, economic and social functions. Some use value or economic valuation of mangrove ecosystem are: (1) direct use value, (2) indirect use value, (3) alternative use value, and (4) existence use value.

\subsubsection{Direct Use Value}

Below is the findings of direct use value of mangrove ecosystem relating to fisheries product: (1) tiger prawn reaches Rp7,587,000, (2) milkfish reaches Rp6,421,500, (3) seaweed reaches Rp3,600,000, (4) uncultivated shrimp reaches $\mathrm{Rp}$ 1,081,000, (5) uncultivated fish reaches Rp1,025,000, (6) mangrove crab reaches Rp14,625,000, (7) shellfish reaches Rp625,000, (8) fry reaches Rp7,303,625,000, and (9) shrimp fry reaches Rp6,025,000. Accordingly, total direct use value of mangrove ecosystem regarding fisheries product is $\mathrm{Rp} 48,303,875 \mathrm{ha}^{-1}$ year $^{-1}$. If this amount is multiplied by $1,351.50$ ha (area of mangrove ecosystem in Sinjai Regency), calculated direct use value reaches Rp65,282,687,062 year $^{-1}$.

The findings on direct use value of mangrove ecosystem and coastal fisheries product shows positive correlation to area expansion of mangrove ecosystem in silvofishery brackishwater pond. The higher ratio of mangrove in silvofishery brackishwater pond, the higher coastal fisheries product will be reached by correlation of $\mathrm{Y}=-0.347+0.520 \mathrm{X}$. It means that every progression of $100 \mathrm{~m}^{2}$, area of mangrove ecosystem will increase production by Rp 520,000. It affirms the findings of Denilla (1987), Niartiningsuh (1996) and Alam (1997) stating that fry and shrimp fry caught in coastal waters of Sinjai Regency is increasing along with expansion area of mangrove ecosystem.

\subsubsection{Indirect Use Value}

Indirect use value of mangrove ecosystem can be divided into two groups as follows: (1) indirect use is in form of physical use, for example to resist abrasion or intrusions of sea water into the ground, to protect residential area from whirlwind, to produce oxygen, and to absorb carbon dioxide, and (2) as a place to spawn, to forage, to take shelter and to grow up. It also functions as nutrient producer for organism inhabiting coastal waters. Additional use of mangrove ecosystem is ecological use, i.e. it functions as biofilter and hatchery provider for brackishwater aquaculture and mariculture.

According to Naamin (1990) and Palevesan, et al. (2005), indirect use value of mangrove ecosystem as provider of various nutritive substances has correlation between mangrove area and coastal fisheries product, especially shrimp product, by $51.97 \mathrm{~kg} \mathrm{ha}^{-1} \mathrm{th}^{-1}$. Indirect use value is sum of multiplication of shrimp product in an area of 1,351.50 ha in Sinjai Regency and average production per kilogram that use value of mangrove ecosystem, especially shrimp, has not included other biota of Rp3,160,685,475 year $^{-1}$.

\subsubsection{Alternative Use Value}

Alternative use value of mangrove ecosystem is calculated based on exchange rate of US\$ and rupiah, when the study is performed, is $\mathrm{Rp} 9,500 \mathrm{US}^{-1}$. Accordingly, if alternative use value of mangrove ecosystem is Rp142,500 $\mathrm{ha}^{-1}$ year ${ }^{-1}$, total use value of mangrove ecosystem in Sinjai Regency in an area of 1,351.50 ha is Rp192,588,750. Alternative use value of mangrove ecosystem is use value which is given when anyone or any group of people visits or travels to mangrove ecosystem by spending some money for the journey. 


\subsubsection{Existence Use Value}

Use value of mangrove ecosystem in Sinjai Regency is calculated by contingent value method (CVM). According to Asbar (2007), existence use value of mangrove ecosystem is Rp2,917,722 ha $^{-1}$ year $^{-1}$, so total use value of mangrove ecosystem in Sinjai Regency in an area of $1,351.50$. ha is $\mathrm{Rp} 3,943,301,283$. The meaning thereof is that the presence of mangrove ecosystem in coastal ecosystem may prevent natural disasters such as tsunami and whirlwind. Furthermore, the presence of this ecosystem may cut down natural disasters prevention budget from the National Revenues and Expenditure Budget.

\subsubsection{Total Use Value of Mangrove Ecosystem}

Analysis of mangrove ecosystem in Sinjai Regency shows that: (1) direct use value of mangrove ecosystem from coastal fisheries product is Rp65,282,687,062 year ${ }^{-1}$, (2) indirect use value of mangrove ecosystem is Rp3,160,685,475 year $^{-1}$, (3) alternative use value of mangrove ecosystem is Rp192,588,750 year $^{-1}$, and (4) existence use value of mangrove ecosystem is Rp3,943,301,283. Total use value of mangrove ecosystem in Sinjai Regency in an area of 1.351 .50 ha is $\mathrm{Rp} 72,580,262,570$ year $^{-1}$

Mangrove ecosystem in Sinjai Regency is 1,351.50 ha. If all of this area is converted into brackishwater pond by application of technology, average product is Rp20,607,750 ha ${ }^{-1}$ year $^{-1}$, and if it is multplied by total area of mangrove ecosytem, the product will be Rp27,851,374,125 year $^{-1}$. Based on the analysis of use value of mangrove ecosystem and fisheries and shrimp product value, if this ecosystem is converted into brackishwater pond by application of technology and traditional method, ecological loss will be Rp44,728,888,445 $\mathrm{th}^{-1}$. Therefore, total use value of mangrove ecosystem will be greater than brackishwater aquaculture.

Analysis of total use value or economic valution of mangrove ecosystem in Sinjai Regency

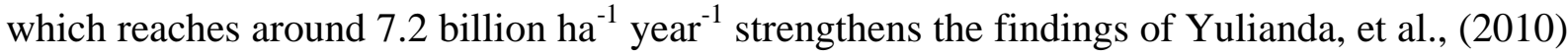

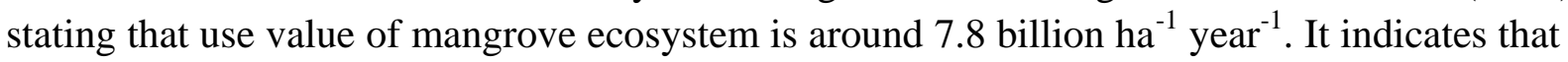
use value of mangrove ecosystem will be greater if it is converted into brackishwater pond by application of technology and traditional method. Therefore, future mangrove ecosystem management in Indonesia shall be directed to silvosery management model. By applying this model, there is an expectation when ecology and economy is integrated to make coastal resources management work optimally and continuously (State-owned forestry firm or Perhutani, 1998) and Zuna (1998).

\section{Closure}

\subsection{Conclusion}

Based on the field study and data analysis, it concludes that: (1) based on analysis result of the four species in mangrove vegetation indicates that vegetation is homogeneous and it is dominated by species Rhizophora at percentage of $86.53 \%$, (2) analysis result of the density of ecosystem shows that mangrove ecosystem is very dense in which average density reaches 10,010 stands $\mathrm{ha}^{-1}$, where density of mangrove vegetation found is higher than 1,500 stands $\mathrm{ha}^{1-}$. Therefore, it is classified as very dense in accordance with the decree of Ministry of Environment the Republic of Indonesia No 201 of 2004, and (3) analysis result of use value or economic valuation of mangrove ecosystem indicates that if mangrove ecosystem is 
converted into brackishwater pond will have adverse effect on ecology.

\subsection{Suggestion}

On the basis of conclusion above, it suggests that: (1) if mangrove rehabilitation is performed, it shall not only focus on target quantity in the form of area and density, but it shall focus on quality, i.e. composition of vegetation since mangrove ecosystem is considered as healthy if it is heterogeneous. It is said that mangrove has been restored if composition of vegetation is heterogeneous and if the area is restored as previous, (2) density of mangrove vegetation shall not more than 5,000 stands ha ${ }^{-1}$, in purpose to make nutrient, air and photosynthesis cycle run optimally. Crossing ditches shall be built in mangrove area as a place of biota assembly at the time tide, and (3) in order to prevent ecological loss if mangrove ecosystem is converted into brackishwater pond, silvofishery management model shall be made; it is a management model of mangrove ecosystem which integrates ecological and economic aspects.

\section{References}

Alam, S. (1997). Kajian Ekonomi-Ekologi Pertambakan pada Ekosistem Mangrove Mengantipasi dampak Pembangunan terhadap Lingkungan Kawasan Pantai. Jurnal Penelitian Pusat studi Lingkungan, 2, 12-21.Universitas Hasanuddin kassar.

Asbar. (2007). Optimalisasi Pemanfaatan Kawasan Pesisir untuk Pengembangan Budidaya Tambak di Kabupaten Sinjai, Sulawesi Selatan [disertasi]. Sekolah Pascasarjana Institut Pertanian Bogor.

Badan, P. S. (2010). Kabupaten Sinjai Dalam Angka 1990. 1995, 2000, 2005, 2007, dan. Buku Kabupaten Sinjai Dalam Angka, Propinsi Sulawesi Selatan.

Bengen, D. G. (2002). Pedoman Teknis Pengenalan dan Pengelolaan Ekosistem Mangrove. Pusat Kajian Sumberdaya Pesisir dan Lautan. Institut Pertanian Bogor. (PKSPL-IPB).

Beukeboom, H., Lai, C. K., \& Otsuka, M. (1992). Report of the Regional Expert Consultation on Partcipatory Agroforestry and Silvofisherry System in Southeast Asia-Pasifik Agroforestry Network.

Dahuri, R., Rais, J., Ginting, S. P., \& dan Sitepu, M. J. (1996). Pengelolaan Sumberdaya Pesisir dan Lautan Secara Terpadu. PT Pradnya Pramita Jakarta.

Denila, L. (1987).. Layout Desain Construction and Levelling of Fishpond. Readings on Aquaculture Practices, SEAFDEC. Aquaculture Departement, Iloilo, Philippines.

Dinas Kelautan dan Perikanan Kabupaten Sinjai, (2012). Potensi Pertambakan. Laporan Tahunan Dinas Kelautan dan Perikanan Kabupaten Sinjai.

Dinas Perikanan dan Kehutanan Kabupaten Sinjai, (2012). Perkembangan luas Hutan mangrove di Kabupaten Sinjai berdasarkan desa dan kelurahan (1991-2010).

Niartiningsih, A. (1996). Studi Tentang Komunitas pada Musim Hujan dan Kemarau di Hutan Bakau Rakyat Sinjai Timur, Kecamatan Sinjai Timur, Kabupaten Sinjai. Tesis Program Pascasarjana Universitas Hasanuddin, Makassar. 


\section{Macrothink}

Palavesan, A. Beena, S., \& Emmanuel, G. (2005). A Method for the estimation of detritus energi generation aguatic. Turkish journal of fisheries andaguatic, 5, 49-52.

Perhutani. (1998). Pelaksanaan Program Perhutanan Sosial dengan Sistem Silvofishery pada Kawasan Hutan Payau di Pulau Jawa. Perum Perhutani Jakarta.

Rachmawati. (2004). Pengembangan Pemanfaatan Ekosistem Mangrove di Sumatra Utara http//library usu.ac.dikunjungi pada tanggal 25 april 2009.

Saru, A. (2007). Kebijakan Pemanfaatan Ekosistem Mangrove Terpadu dan Berkelanjutan di Kabupaten Barru, Sulawesi Selatan. Disertasi Sekolah Pascasarjana Institut Pertanian Bogor.

Sofyan. (2001). Desentralisasi Pengelolaan Sumberdaya Pesisir dan Lautan. SuatuTantangan dan Peluang. [tesis] Program Pascasarjana Institut Pertanian Bogor.

Suprihariyno. (2005). Konservasi Sumberdaya Hayati di Wilayah Pesisir dan Laut Tropis. Pustaka Pelajar, Yogyakarta.

Yulianda, F., Fahrudin, A., Adrianto, L., Hutabarat, A., Herteti, A., Kusharyani, S., \&.Kang, H. S. (2010). Kebijakan Konsevasi Perairan Laut dan Nilai Value Ekonomi. Pusdiklat Kehutanan .Departemen Kehutanan Republik Indonesia.

Zuna, M. Y. (1998). Analisis Ekologi- Ekonomi system tambak tumpangsari di RPH. Proponcol Desa Mayangsari Kabupten Subang. Tesis Magister Program Pascasarjana Institut Pertanian Bogor.

\section{Copyright Disclaimer}

Copyright for this article is retained by the author(s), with first publication rights granted to the journal.

This is an open-access article distributed under the terms and conditions of the Creative Commons Attribution license (http://creativecommons.org/licenses/by/3.0/). 